\title{
ANALISIS KARAKTERISTIK PENGUNJUNG DI DEPATI VII COFFEE KOTA SUNGAI PENUH
}

\author{
DITOP ANDRA VOLTA, TRISNA PUTRA \\ Fakultas Pariwisata dan Perhotelan Universitas Negeri Padang \\ ditopandravolta@gmail.com,tpo3tra@gmail.com
}

\begin{abstract}
This study originated from the observations of researchers during observations at Depati VII Coffee. Researchers found several problems related to the characteristics of visitors such as the absence of data on the characteristics of visitors visiting Depati VII Coffee. There is no visitor classification data from demographic, geographical and psychographic aspects. The general purpose of this observe changed into to research the characteristics of traffic journeying Depati VII Coffee. The form of studies used on this observe is quantitative with survey methods. In the survey, records become amassed from respondents the use of questionnaires or questionnaires dispensed directly. The variables on this take a look at are self-contained variables which can be characteristics of visitors. The populace on this take a look at had been all visitors who got here to go to Depati VII Coffee with a complete pattern of 100 respondents. The effects of this take a look at were examined for validity and reliability. The information evaluation strategies used are descriptive information with Microsoft excel and SPSS. The effects of the take a look at concluded that almost all of site visitors visited Depati VII Coffee. aged 18 - 24 years as much as 77\%, for the sex most obtained by the male gender 55\%, for the last education is high school 75\%. The type of work obtained from 100 ecutioners distributed to visitors at Depati VII Coffee gets $74 \%$ of students/ students, for marital status $86 \%$ of visitors are unmarried. Geophysical characteristics of visitors who come to Depati VII Coffee, there are $61 \%$ of the area of Sungai Penuh City jambi Province, based on the location where visitors visit Depati VII Coffee there are $95 \%$ of visitors living in densely populated housing, for the plains where visitors live $92 \%$ come from highland areas around 700 MDPL. Psychographic characteristics of visitors who come to Depati VII Coffee Based on Psychographic Characteristics the majority of visitors with type experiencers with a total of $64 \%$ and $36 \%$ of visitors with type.
\end{abstract}

Keywords: Demographic Characteristics, Geographic Characteristics, Psychographic Characteristics

\begin{abstract}
Abstrak: Penelitian ini berawal dari pengamatan peneliti saat observasi di Depati VII Coffee peneliti menemukan beberapa permasalahan terkait karakterisrik pengunjung seperti tidak adanya data mengenai karakteristik pengunjung yang berkunjung di Depati VII Coffee dan tidak ada data klasifikasi pengunjung dari aspek demografis, geografis dan psikografis. Tujuan umum pada penelitian ini adalah untuk menganalisis karakteristik pengunjung yang berkunjung di Depati VII Coffee. Jenis penelitian ini menggunakan metode kuantitatif dengan metode survey. Dalam survey, data responden dikumpulkan menggunakan angket atau kuesioner yang didistribusikan langsung. Variabel pada penelitian ini adalah variabel mandiri yaitu karakteristik pengunjung. Populasi pada penelitian ini semua pengunjung yang datang berkunjung ke Depati VII Coffee dengan sampel sebanyak 100 responden. Uji validitas dan reliabilitas telah dilakukan pada penelitian ini. Teknik analisis data yang digunakan adalah statistik deskriptif dengan batuan Microsoft excel dan SPSS. Hasil penelitian menyimpulkan bahwa mayoritas pengunjung yang berkunjung di Depati VII Coffee. berumur $18-24$ tahun sebanyak $77 \%$, untuk jenis kelamin yang paling banyak diperoleh oleh jenis kelamin laki - laki $55 \%$, untuk pendidikan terakhir yaitu SMA 75\%. Jenis Pekerjaan yang diperoleh dari 100 rekuesioner yang dibagikan kepada pengunjung di Depati VII Coffee mendapatkan $74 \%$ pelajar/mahasiswa, untuk status perkawinan $86 \%$ pengunjung berstatus belum menikah. karakteristik georafisnya pengunjung yang banyak datang ke Depati VII Coffee, terdapat $61 \%$ dari dalam area Kota Sungai Penuh Provinsi jambi, berdasarkan lokasi tempat tinggal pengunjung yang mengunjungi Depati VII Coffee terdapat $95 \%$ pengunjung tinggal di
\end{abstract}


perumahan padat penduduk, untuk dataran tempat tinggal pengunjung 92\% berasal dari daerah dataran tinggi kisaran 700 MDPL. Karakteristik psikografis pengunjung yang banyak datang ke Depati VII Coffee Berdasarkan Karakteristik Psikografis mayoritas pengunjung dengan tipe experiencers dengan jumlah sebanyak $64 \%$ dan $36 \%$ pengunjung dengan tipe makers.

Kata Kunci: Karakteristik Demografis, Karakteristik Geografis, Karakteristik Psikografis

\section{A. Pendahuluan}

Pariwisata merupakan kegiatan yang ditujukan untuk memberikan pelayanan wisata, memberikan dan memelihara daya tarik wisata, usaha pariwisata, dan usaha lain yang terkait di bidang ini [1]. Pariwisata adalah "aktivitas seseorang yang pindah atau menetap di suatu tempat diluar lingkungan untuk waktu tidak lebih dari satu tahun berturut-turut, untuk kesenangan, bisnis atau tujuan lain."[2] Secara umum pariwisata dapat diartikan sebagai sebuah kegiatan yang dilakukan seseorang untuk melakukan suatu kegiatan rekreasi ke tempat yang memiliki potensi dan dapat dinikmati.

Industri pariwisata yang terkait dengan sarana dan prasarana merupakan faktor yang sangat penting untuk mendukung pertumbuhan industri pariwisata. Sarana dan prasarana dapat menjadi salah satu faktor pendukung daya tarik wisata. Sarana pariwisata adalah kumpulan daya tarik wisata yang diperlukan untuk dapat memberikan pelayanan kepada wisatawan untuk menikmati perjalanannya baik secara langsung maupun tidak langsung [3]. Sarana Pariwisata adalah segala sesuatu yang lengkap dan ditujukan untuk memperlancar kegiatan perjalanan [4]. Prasarana merupakan fasilitas yang membuat proses ekonomi berjalan lancar dengan memfasilitasi pemenuhan kebutuhan pengunjung.

Sarana dan prasarana penunjang, khususnya produk pariwisata, meliputi unsur-unsur yang dapat diklasifikasikan menjadi 4A yaitu atraksi, aksesibilitas, kenyamanan, dan aktivitas [5]. Salah satu unsur 4A adalah amenititas yang meliputi segala fasilitas yang dipakai untuk mencukupi kebutuhan akomodasi, pengadaan makanan dan minuman, tempat hiburan, perbelanjaan dan pelayanan lainnya [6].

Salah satu bentuk contoh Amenitas adalah Cafe yaitu jenis restoran yang biasanya menyajikan kopi atau teh dan juga makanan ringan. Di kota Sungai Penuh memiliki salah satu tempat wisata yang memiliki Cafe yaitu Depati VII Coffee. Depati VII Coffee menawarkan berbagai macam olahan kopi dan juga wisata kebun kopi. Campground, dan juga edukasi tentang kopi. Depati VII Coffee ini dapat diakses melalui jalur Padang via Tapan tepatnya di kilometer 5 puncak Kota sungai penuh yaitu sekitar 30 sampai 40 menit dari kota Sungai Penuh lokasi ini memberikan keuntungan seperti pemandangan Gunung Kerinci dan Danau Kerinci.

Pengunjung biasanya datang ke Depati VII Coffee untuk menikmati berbagai olahan kopi untuk piknik dan berswafoto dengan fasilitas-fasilitas yang telah disediakan oleh Depati VII Coffee. berbagai kegiatan yang dilakukan oleh pengunjung tak lepas dari berbagai macam karakter setiap pengunjung. Hal ini berpengaruh terhadap jumlah kunjungan karena karakter setiap pengunjung lebih menyukai tempat yang memadai yang sesuai dengan karakter masingmasing pengunjung. pengunjung lebih memilih tinggal di tempat yang mudah dikunjungi, dimana akomodasi memiliki kualitas yang baik, harga terbaik dan fasilitas yang lengkap [7]. Dan salah satu yang paling trending adalah Karakter para traveller yang senang berwisata ke destinasi yang menawarkan tempat berkumpul atau co-working space.

Tabel 1. Data Kunjungan Juli - Desember 2020 Pengunjung di Depati VII Coffee

\begin{tabular}{|c|c|c|}
\hline No & Bulan & Jumlah Kunjungan \\
\hline 1. & Juli & 7.004 \\
\hline 2. & Agustus & 6.024 \\
\hline 3. & September & 4.986 \\
\hline 4. & Oktober & 4.032 \\
\hline 5. & November & 3.405 \\
\hline 6. & Desember & 6.809 \\
\hline
\end{tabular}

28 Lembaga Penelitian dan Penerbitan Hasil Penelitian Ensiklopedia 
Terlihat pada tabel di atas bahwa pengunjung di Depati VII Coffee dari bulan Juli Desember 2020 masih belum stabil. Sehingga hal ini mempengaruhi karakteristik pengunjung yang berkunjung di Depati VII Coffee. adapun pengertian dari Karakteristik adalah suatu ciri khas berupa kepribadian, watak, serta corak tingkah laku atau tanda khas yang dimiliki oleh setiap individu. Karakteristik yang berasal dari kata personality berarti sifat-sifat psikologis, moral atau kepribadian yang membedakan seseorang dengan orang lain. Karakteristik Pengunjung terdiri dari 3 aspek yaitu aspek psikografis, aspek demografis dan aspek geografis [8]. Berdasarkan hasil observasi peneliti pada bulan April 2021 terlihat beberapa permasalahan terkait karakteristik pengunjung di Depati VII Coffee. Pada destinasi wisata Depati VII Coffee ini belum terdapat data-data khusus karakteristik untuk yang berkunjung, sehingga pengelola hanya dapat membuat data kunjungan di Depati VII Coffee. Peneliti juga melihat bahwa dari data kunjungan yang diperoleh dari Depati VII Coffee terlihat jumlah kunjungan belum stabil. Maka daripada itu penelitian ini penting dilakukan untuk mengetahui apakah fasilitas - fasilitas yang ada di Depati VII Coffee sesuai dengan karakteristik pengunjung dan bagaimana karakteristik pengunjung yang datang berkunjung ke Depati VII Coffee dari berbagai aspek-aspek yang ada pada indikator karakteristik pengunjung yang berguna bagi Depati VII Coffee kedepannya.

\section{B. Metodologi Penelitian}

Jenis penelitian ini adalah kuantitatif dengan metode survey, jenis data yang digunakan adalah data primer dan data sekunder. Penelitian deskriptif adalah gejala-gejala menurut apa adanya pada saat penelitian itu dilakukan [9]. Metode kuantitatif dapat didefinisikan sebagai metode yang didasarkan pada filosofi positivis, dipakai untuk meneliti populasi atau sampel tertentu. Mengumpulkan data dengan memakai alat penelitian, menganalisis data kuantitatif/statistik untuk tujuan mendeskripsikan dan menguji hipotesis yang telah ditentukan [10]. Variabel dalam penelitian ini terdiri dari satu variabel yaitu Karakteristik Pengunjung di Depati VII Coffee Kota Sungai Penuh. Populasi untuk penelitian ini adalah 32.260 dengan jumlah sampel di atas dibulatkan menjadi 100, dianggap representatif karena berada di atas batas sampel minimal 30. Tipe data ini menggunakan data primer dan data sekunder. Data diambil menggunakan alat ukur berupa kuesioner skala Guttman, data diperoleh sebagai data interval atau bivariat (dua alternatif), untuk "ya" dan tidak". Uji coba pada instrumen penelitian ini adalah uji validitas dan uji reliabilitas. Data dianalisis dengan menggunakan bantuan microsoft excel dan SPSS versi 20.00 dengan pengolahan data yang digunakan adalah mentabulasi data dan deskriptif data.

\section{Hasil dan Pembahasan}

\section{Karakteristik Demografis}

Berdasarkan hasil penelitian dari kuesioner telah dibagikan kepada 100 responden terdapat $77 \%$ pengunjung Depati VII Coffee yang berumur $18-24$, pengunjung yang berumur 25 - 34 sebanyak $18 \%$, pengunjung berumur $35-44$ mendapatkan persentase $3 \%$, pengunjung yang berumur 45 - 54, dan pengunjung umur 55- 65 tahun tidak ada yang mengunjungi objek wisata Depati VII Coffee Kota Sungai Penuh. Berdasarkan jenis kelamin didominasi oleh pengunjung laki- laki dengan jumlah persentase terdapat 55\% adalah laki laki, dan $45 \%$ adalah perempuan yang mengunjungi objek Depati VII Coffee kota Sungai Penuh. Berdasarkan pendidikan terakhir 0\% pengunjung tamat SD, sebanyak 8\% SMP, 75\% adalah SMA, $2 \%$ adalah pengunjung yang tamatan Diploma, dan 15\% pengunjung tamatan Sarjana yang mengunjungi objek wisata Depati VII Coffee.

Dari hasil sebaran kuesioner yang disebarkan pada pengunjung objek Wisata Depati VII Coffee berdasarkan Pekerjaan pengunjung mendapatkan hasil. $74 \%$ pengunjung yang bekerja sebagai pelajar/mahasiswa, 8\% Wirausaha, 9\% sebagai PNS/Pegawai Militer, 5\% Karyawan Swasta, 3\% Profesional, dan 1\% pengunjung bekerja sebagai Ibu Rumah Tangga yang mengunjungi Wisata Depati VII Coffee. Hasil penelitian dapat dijelaskan status 
perkawinan pengunjung yang berkunjung ke Depati VII Coffee Kota Sungai Penuh, terdapat $86 \%$ pengunjung berstatus belum menikah, $14 \%$ menikah, dan $0 \%$ Cerai.

\section{Karakteristik Geografis}

Dari hasil penelitian berdasarkan karakteristik geografis pengunjung menurut kota tempat tinggal. Terdapat $61 \%$ pengunjung tinggal dalam area Kota Sungai Penuh, 33\% pengunjung berasal dari luar Kota Sungai Penuh dalam Provinsi Jambi, dan 6\% pengunjung yang berasal dari luar Provinsi Jambi dalam Indonesia. Hasil penelitian berdasarkan Dataran Tempat Tinggal terdapat 92\% pengunjung di Wilayah Dataran Tinggi(Kisaran 700 MDPL), dan 8\% Wilayah Dataran Rendah(Kisaran 200 MDPL).

\section{Karakteristik Psikografis}

Dalam penelitian ini dilakukan untuk melihat ciri psikografis pengunjung yang datang ke objek wisata Depati VII Coffee Kota Sungai Penuh apakah termasuk kedalam experiencers atau makers. Untuk mengetahui karakteristik tersebut, penulis memberikan 8 jawaban untuk responden, 6 pertanyaan untuk yang experiencers dan 2 pertanyaan untuk makers. Untuk pernyataan yang experiencers, jika responden menjawab "Ya" maka responden memilih karakternya sendiri sebagai yang experiencers, jika menjawab "Tidak" maka responden memilih makers. Untuk pernyataan makers ,jika responden menjawab "Ya", maka responden tersebut memilih diri mereka sebagai makers dan sebaliknya jika responden tersebut menjawab "Tidak", maka responden tersebut memilih diri mereka sebagai experiencers. Berikut penulis telah mempersentasikan jawaban dari 8 pernyataan yang telah penulis berikan.

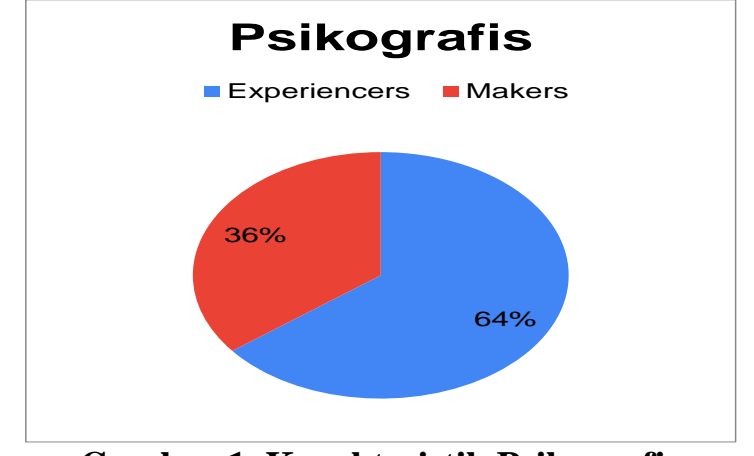

\section{Pembahasan}

\section{Gambar 1. Karakteristik Psikografis}

Berdasarkan hasil penelitian di atas maka dapat dibuat pembahasan mengenai Karakteristik pengunjung di wisata Depati VII Coffee Kota Sungai Penuh Penelitian Karakteristik pengunjung ini ditinjau dari 3 indikator, yaitu: 1. Karakteristik Demografis. 2.Karakteristik Geografis.3.Karakteristik Psikografis. Berikut Penulis uraikan pembahasan mengenai karakteristik pengunjung lokal di wisata Depati VII Coffee Kota Sungai Penuh.

\section{Karakteristik Demografis}

a. Usia

Berdasarkan data yang didapat dari 100 responden, pada umumnya pengunjung yang datang ke Depati VII Coffee Kota Sungai Penuh berada pada rentang usia 18 - 24 tahun yaitu sebanyak $77 \%$.

b. Jenis Kelamin

Berdasarkan dari kuesioner Analisis Karakteristik Pengunjung yang telah disebarkan kepada 100 orang responden. Terdapat 55\% responden berjenis kelamin Laki - Laki.

c. Tingkat Pendidikan

Mayoritas pengunjung memiliki pendidikan di tingkat SMA/Sederajat, yaitu sebanyak 75\% hal ini karena pada rentang usia $18-24$ tahun masih banyak yang mengenyam bangku sekolah ataupun kuliah.

d. Pekerjaan

$\begin{array}{lll}30 & \text { Lembaga Penelitian dan Penerbitan Hasil Penelitian Ensiklopedia } & \text { E-ISSN: 2657-0300 } \\ & \text { P-ISSN: 2657-0319 }\end{array}$


Karena mayoritas pengunjung masih berusia antara 18 hingga 24 tahun, maka mayoritas pengunjung, khususnya $72 \%$ responden, masih bersekolah atau kuliah.

e. Status Perkawinan

Dari 100 orang responden mayoritas responden yang didapatkan masih dalam status belum menikah yaitu sebanyak 86\%, 14\% Menikan, dan 0\% nya berstatus Cerai.

\section{Karakteristik Geografis}

a. Kota Tempat Tinggal

Dari hasil penelitian dapat dilihat bahwa mayoritas pengunjung yang berkunjung ke objek wisata Depati VII Coffee Kota Sungai Penuh berasal dari dalam area dalam Kota sungai Penuh itu sendiri, dari kuesioner yang diberikan ke 100 responden sebanyak $61 \%$ pengunjung berada dalam area Kota Sungai Penuh.

b. Lokasi Tempat Tinggal

Berdasarkan hasil data kuesioner yang telah disebarkan ke 100 responden, mayoritas pengunjung yang datang ke objek wisata Depati VII Coffee Kota Sungai Penuh berlokasi tinggal di Perumahan Padat Penduduk sebanyak 95\%.

c. Dataran Tempat Tinggal

Berdasarkan hasil data jawaban dari 100 responden. Mayoritas pengunjung berasal dari daerah dataran tinggi(diatas 700 MDPL) sebanyak 92\%.

\section{Karakteristik Psikografis}

Berdasarkan kuesioner yang telah di sebarkan kepada responden. pengunjung yang datang ke objek wisata Depati VII Coffee Kota Sungai Penuh mayoritas masuk kedalam type pengunjung experiencers sebanyak $64 \%$ dan hanya $36 \%$ yang masuk type makers. Dari hasil tersebut dapat dinyatakan bahwa pengunjung yang berkunjung ke objek wisata Depati VII Coffee Kota Sungai adalah pengunjung yang loyal dan berjiwa muda yang menyukai produk dan layanan yang baik, baru dan unik.

\section{Penutup}

Karakteristik Demografis. Mayoritas pengunjung yang berkunjung di objek wisata Depati VII Coffee Kota Sungai Penuh Yang berumur 18-24 tahun sebanyak 77\%, untuk jenis kelamin yang paling banyak diperoleh oleh jenis kelamin laki - laki sebanyak 55\%, untuk Pendidikan Terakhir. SMA 75\%. Jenis Pekerjaan yang diperoleh dari 100 kuesioner yang dibagikan kepada pengunjung di kawasan wisata Depati VII Coffee mendapatkan Pelajar/Mahasiswa sebanyak 74\%. Penulis mendapatkan $86 \%$ pengunjung yang belum menikah yang mengunjungi wisata Depati VII Coffee Kota Sungai Penuh. Karakteristik Geografis. Berdasarkan karakteristik geografisnya pengunjung yang banyak datang ke daya tarik wisata di Depati VII Coffee Kota Sungai Penuh, terdapat $61 \%$ pengunjung tinggal di dalam area kota Sungai Penuh, berdasarkan lokasi tempat tinggal pengunjung yang mengunjungi wisata Depati VII Coffee Kota Sungai Penuh terdapat 95\% pengunjung berlokasi di daerah Perumahan Padat Penduduk. Dan untuk mengetahui Persentase Dataran Tempat Tinggal pengunjung mendapatkan $92 \%$ berasal dari wilayah dataran tinggi(kisaran 700 MDPL). Karakteristik Psikografis. Karakteristik pengunjung yang datang daerah wisata Depati VII Coffee Kota Sungai Penuh dikunjungi oleh Pengunjung memiliki karakteristik psikografis dari tipe experiencers hingga 64\%, yang menunjukkan bahwa pelanggan yang datang ke Depati VII Coffee adalah anak muda dan mereka juga mudah menerima tren atau produk atau layanan yang baru dan bagus.

\section{Daftar Pustaka}

Utama, A. Y., \& Nurgiyatna, S. T. (2017). Penggunaan Augmented Reality Sebagai Media Promosi Pariwisata Di Kabupaten Karanganyar (Doctoral dissertation, Universitas Muhammadiyah Surakarta).

Wahid, A. (2015). Strategi Pengembangan Wisata Nusa Tenggara Barat Menuju Destinasi Utama Wisata Islami. Universitas Muhammadiyah Yogyakarta. 
Sinarta, I. N. (2021). Investasi Pariwisata Indonesia (Book Chapter)" Mitigasi Bencana Geologi Terhadap Investasi Pariwisata Di Indonesia".

Warang, T. R., Rondonuwu, D. M., \& Warouw, F. (2015). Kajian Pengembangan Wisata Pantai di Pulau Sulabesi Kabupaten Kepulauan Sula Provinsi Maluku Utara. spasial, 1(1), 113-122.

Wilopo, K. K., \& Hakim, L. (2017). Strategi pengembangan destinasi pariwisata budaya (studi kasus pada kawasan situs Trowulan sebagai pariwisata budaya unggulan di Kabupaten Mojokerto). Jurnal Administrasi Bisnis (JAB), 41(1), 56-65.

Salsabila, Y. (2019). Karakteristik Wisatawan Milenial Dalam Meningkatkan Daya Saing Produk Wisata di Orchid Forest Bandung. repository.stp-bandung.ac.id

Setiawan, A. B. (2016). Peningkatan Keamanan Supervisory Control And Data Acquisition (SCADA) Pada Smart Grid Sebagai Infrastruktur Kritis. Jurnal Penelitian Pos dan Informatika, 6(1), 59-78.

Arikunto, S. (2010). Prosedur Penelitian Suatu Pendekatan Praktik. Jakarta: Rineka Cipta.

Sugiyono. (2018). Metode Penelitian Kuantitatif. Bandung: Alfabeta.

Ghani, Y. A., \& Brahmanto, E. (2015). Pengaruh Inovasi Sarana Prasarana Terhadap Kepuasan Pengunjung di Objek Wisata Karangsetra Waterland. Jurnal Pariwisata, 2(2), $98-110$. 